УДК 821.113 .6

Polina Lisovskaya

St. Petersburg State University

\title{
CHILDREN AND «PRODIGAL SONS»: ON IMAGES OF CHILDREN IN STRINDBERG'S WRITING
}

The theme of childhood and images of children in Strindberg's writing have been largely overlooked by the scholars with the few exceptions. As a rule, focal attention in the studies of Strindberg's work is given to the way the roles of the sexes and conjugal tensions function in his drama and prose. However, such problems as child upbringing, parental responsibility and 'fathers and sons' conflicts concerned Strindberg throughout his entire life, following his own evolution as writer and playwright. The development of child imagery in Strindberg's work aligns him with the great authors of the nineteenth century, primarily with Dickens, Hugo, Zola, Ibsen, and Dostoyevsky. This study shows that several types of child images can be distinguished in Strindberg's writing both during the pre-Inferno and the post-Inferno periods. These are 'Child as Victim', 'Perfect Child,' 'Child as Angelic Creature, 'Child as Savior', as well as 'Evil Children' and 'enfants terribles' of various kinds. The imagery of children in Strindberg's writings of the 1900s are of special interest, because they represent the most mature stage of his life and literary activity, and were created after he had lived through significant psychological, philosophical, and spiritual crises, including his religious conversion to Christianity. The latter part of the article is devoted to a motif, which proved to be productive in Strindberg's later oeuvre, namely 'the return of the long lost son', which form a natural juxtaposition to the evangelic parable of the prodigal son. Apart from the above it was found interesting to point out to some evident typological similarities between Strindberg's Black Banners (1904) and Dostoyevsky's Demons (1872) echoing each other in their treatment of 'fathers and sons' theme and in the sharp critique of the nineteenth century liberalism.

Keywords: Strindberg, Dostoyevsky, "Demons", Dickens, images of children, the prodigal son motif, Enlightenment rationalism, nineteenth century liberalism.

\section{П.А. Лисовская \\ Санкт-Петербургский государственный университет}

ДЕТИ И «БЛУДНЫЕ СЫНОВЬЯ»: К ВОПРОСУ О ДЕТСКИХ ОБРАЗАХ У СТРИНДБЕРГА

Тема детства и детских образов не относится к хорошо изученным областям в исследованиях, посвященных творчеству Августа Стриндберга. Как правило, акцент делается на теме отношений между полами и проблемах супружества в драматургии и прозе великого шведа. Однако ответ на вопрос о том, как имен- 
но функционирует в творчестве Стриндберга образ ребенка и тема детства как таковая, включая аспекты как нравственного, так и физического воспитания, мог бы способствовать полноте анализа и в целом лучшему пониманию художественного, философского и духовного мира этого писателя. В статье предлагается обзор типов и стратегий изображения детства и детей в творчестве Стриндберга как в ранний натуралистический, так и в поздний период его творчества, а также анализируется их символическое значение и функция в структуре «стриндберговской семьи». Делается вывод о том, что в позднем творчестве Стриндберг отходит и от руссоистской, и от диккенсовской модели изображения ребенка, характерных для его творчества в 1880 -е, и постепенно начинает включать в свои тексты имманентно злых и испорченных порочным воспитанием детей, тем самым уравнивая ребенка с воспитавшим его взрослым. В конце статьи говорится о ранее не замечавшихся исследователями типологических сходствах между последним большим социально-критическим романом Стриндберга «Черные знамёна» и романом Достоевского «Бесы», проходящих как раз по линии отношений «отцов и детей». Оба автора в определенный момент в равной мере критически относятся к завоеваниям Просвещения и ценностям либерализма девятнадцатого века.

Ключевые слова: Стриндберг, Достоевский, «Бесы», Диккенс, детские образы, мотив блудного сына, рационализм эпохи Просвещения, либерализм девятнадцатого века.

Although marriage and gender represent the core subjects in Strindberg's writing, one other theme that is particularly worthy of reassessment is the phenomenon that I call the 'Strindbergian family' [Лисовская, 2002]. Given this background, the necessity to refocus Strindberg studies and to give more attention to less studied themes in his work has been emphasized by some scholars [e.g., Olsson, 1999; Robinson, 2000]. The theme of childhood and children, the forms and functions of child imagery within this 'Strindbergian family', and their evolution have been largely overlooked by Strindberg studies with very few exceptions [Szalczer, 2008]. However, the themes of parental responsibility and child upbringing concerned Strindberg a great deal both in the preInferno and post-Inferno periods of his life as if following the stages of his artistic, philosophical, and religious transformations. In this study, we will touch upon a selection of Strindberg's works. Namely, The Father (1886), The Son of Servant (1887), and some stories from Married I-II (1884, 1886) from the pre-Inferno period; and Alone (1903), The Gothic Rooms (1904), Black Banners (1904, publ. 1907), Chamber plays (1907) all belonging to his post-Inferno writing.

On the one hand, the development of childhood theme aligns Strindberg with Dickens, who paid exceptional attention to it throughout his 
career; to summarize Dickens' vision, the child is a lonely victim of the cruel world of adults, but being good and pure by nature the young soul detests and resists corruption. This stance is more or less true for Strindberg of the 1880-s. Within French literature of the first half of the nineteenth century, extensively read by Strindberg, "the child rejected by family or peers, comes to represent the sense of alienation in a world whose parameters seem to have altered" [Lloyd, p.241]. Moreover, the child imagery evolved over time. Lloyd states that closer to the end of the century, "while the child is frequently depicted as a prey to both physical and metaphysical suffering, there is nevertheless the beginning of that urge to happiness..." [Lloyd, p.244]. Strindberg was influenced by the French writers (e.g. Hugo, Balzac), who paid close attention to the theme of the child role in the changing world. Speaking of Strindberg's contemporaries, in Ibsen's dramas, whom the Swede considered one of his primary competitors, children are both angels and victims [Ruff, 1991]. And in this sense Strindberg is closer to Ibsen than he probably wished to be. Nevertheless, he goes further than both Dickens and Ibsen, as he assumes that adults, which can turn a child into a predator, and make an adult a prey, can successfully corrupt a child's soul.

Strindberg is concerned and compassionate about children, but his general suspiciousness and skepticism are valid for children as well. In The Gothic Rooms Strindberg argues with Ellen Key, a renowned educator of the early 1900s, famous for proclaiming the nineteenth century "the child's age", and states that especially the end of the nineteenth century had become "children's hell" [barnens helvete] [Strindberg, 2010, s. 140]. In The Blue Book Strindberg wrote: "I have said that the child is a little criminal, incapable of self-guidance, but I love children all the same" [Strindberg, 1997, s. 156]. Strindberg created a rich repertoire of images of children, employing the ones that were similar to his predecessors and those extremely innovative for his time, which makes the author a precursor of the turn-of-the-century modernism.

My interpretation is that the primary function of child images is to uncover the adults' attitudes towards children, and to provide a moral commentary on the ways of their upbringing. This function is well represented by Dickens' child characters. Lloyd suggests that images of children reflect the adults' perception and beliefs in those characteristics [Lloyd, p. 243]. Speaking at a higher level of generality, child imagery reveals the adults' social and religious belief systems. The images of 
children may also be interpreted as representations of the adults' inner worlds on a deeper level, i.e., as reflections of their search for identity and examination of one's conscience. It is supported by Jung's theory of archetypes, where the child image is a symbol, and one of the main archetypes of collective unconsciousness that acts as an organizing principle on the things we see or do, and that can be found in mythology and art [Jung, 1958, p. 124]. Thus, I suggest reading the following child image-types and their symbolic meanings in Strindberg's work:

- 'Child as Victim' of parental abuse. Its symbolic meaning is in condemnation of the corrupt bourgeois family with its physically and mentally destructive child-rearing practices.

- 'Perfect Child,' 'Child as Angelic Creature,' and 'Child as Savior' are the symbols of faith in the inner goodness of a child. 'Evil Children' would be the opposite type here. These are enfants terribles of various kinds. Symbolically, these images challenge the belief in the good nature of children (and human beings in general), and reflect the deep pessimism of the author regarding the betterment of human race and its social institutions.

- 'The return of the long lost son' is a prominent motif and imagetype in the post-Inferno period. In political terms, its occasions reflect Strindberg's critique of modern liberalism and its political consequences of breeding nihilism and radicalism. My vision is that the 'fathers and sons' theme in Strindberg's later oeuvre corresponds to and has typological coherence with some of Dostoyevsky's interpretation of the same subject, especially in his Demons (Бecbl, 1872).

The image of the child as victim is not unique for Strindberg. It was a common theme for the literature representative of the ideas of the Enlightenment. In his early years, Strindberg ardently condemned the family as a social institution that was hell for children and he even supported state parenthood. However, he soon "disavowed" this radical socialist agenda [Heller, p. 83]. His critique of the family shifted from its condemnation as such to examination of the child-rearing practices within the bourgeois family of the era of modern liberalism. It seems that around 1886-1887, Strindberg was still a believer in Rousseau's concept of the child as tabula rasa, whose fulfillment depends on the influences from the outside world, either uplifting and/or harmful. Therefore, his images of childhood in those years are represented in the con- 
text of child-rearing experimentation by the adults with unpredictable outcomes. For example, in The Father Bertha's future is ambiguous while her parents are arguing about how she is to be educated and who she is to become, an artist or a teacher. Another example is Fritiof in The Child (Barnet) from Getting Married II (1886) brought up by overprotecting women, which lead to unhappy marriage and alcoholism.

In The Son of a Servant, we encounter a portrayal of the child's life given as a succession of events and sufferings caused by the injustices of its family, school, church, and other social institutions. To increase the impression that this type of upbringing is anomalous and conducive to the alienation from the true self, '[i]n a clinical third person discourse, Johan, the main character, is portrayed as if he were just as foreign as a French peasant. An ordinary Swedish childhood is defamiliarized into a piece of ethnographica...' [Stounbjerg, 2009, p. 49].

The corruptive impact of family socialization is rendered in full scale much later in a chamber play The Pelican, in which the son told his sister about the scenes he had happened to witness when he was little, but was punished as a liar after having repeated the same story to the mother. This episode is analogous to the one with the finished wine bottle from The Son of a Servant. ${ }^{1}$ This imagery conveys Strindberg's accusation of parents for teaching their own children to lie, and, thus, corrupting them morally, and then physically.

In the Gothic Rooms, the theme of physical and moral deformity, lack of will and mental retardation as the outcomes of ruined marriages, unwanted pregnancies, and feeding by wet nurses reaches its height. Especially in the later prose, Strindberg's visions of harmonious and loving relationships within the family bear mythological and surrealistic features, suggesting considerable skepticism in their existence and the sorrow of witnessing none of those. The happiness of fatherhood is revealed through reminiscences, hallucinations, and observations of other people's happiness (Inferno, Stormy Weather, Alone).

A child as a path to salvation was generally a popular theme in literature of the nineteenth century, when redemption was often reached through a child's death. Strindberg, however, rarely uses this trope, in contrast to Ibsen, who depicts infanticide and child-death in a number

${ }^{1}$ Johan was falsely accused of and punished for drinking up the rest of the wine from a bottle. 
of his plays [Ruff, p. 124-130]. ${ }^{2}$ In the post-Inferno prose, the child imagery increasingly acquires sinister and demonic features. We encounter more child characters, which are physically and morally repulsive. From the early ages they look and act like little predators and rascals, often as victimizers of their parents and strangers (in Black Banners professor Stenkåhl's step-daughter Sally, referred to as 'the little demon', and Zachris' sons called 'the fox-terrier couple').

Apparently after having explored and practiced the possibilities of a traditional Bildungsroman in the 1880s, in the 1900s Strindberg abandoned the theme of a stolen childhood, and took departure from the child as a tabula rasa concept. His focus shifts to the search for hereditary deficiencies in children thus supporting Nietzsche's view that 'the race had deteriorated in consequence of its sentimentality, namely, through the systematic production of physical and mental inferiority and unchecked procreation of weaklings' [Heller, 1918, p. 96].

Another theme that gains strength in the post-Inferno writing is the impact of modern education built on lofty liberal values as a factor in children's physical and moral decay. It is not clear which factor Strindberg considers of primary importance in shaping the child's personality. For example in Black Banners heredity is clearly a factor since both of the boys' parents are depicted as degenerate and repulsive types, while modern liberal values and education is another factor of decay considering the character Hanna Paj, a grim caricature of Ellen Key in this novel.

The second type of 'evil children' imagery goes far beyond the conceptions of heredity and education. This type promotes a very gloomy perspective of human nature. An example of the 'evil child' as a scary stranger appears in Stormy Weather. A little girl in the park suddenly bites the Gentleman's granddaughter on the cheek [Strindberg, 1973, p.117]. Strindberg gives this image a symbolic meaning of the first meeting with the human evil and of presence of evil in the child as such. Deviating from Dickens' paradigm that even the most evil adults cannot turn children into monsters, Strindberg shows children who will never become good adults. If, according to Jung, child images represent possibility, future, and craving for a new and better self, the little bikers,

2 The theme of infanticide is rendered in There are Crimes and Crimes (1899), and The Crown Bride (1901). 
whom the protagonist in the novel Alone meets during his promenade, symbolize the deepest level of Strindberg's despair and disbelief in these options for himself and for the outside world. It is remarkable, that these prophets of alienation and death are children. The post-Inferno imagery of evil children is in line with the child-image perspectives in drama closer to the end of the nineteenth century, when '...the children become more bizarre. [...] ... purity has become a strange quality [...] and no longer spiritually superior; innocence is more a perversion...' [Ruff, 1991, p. 179]. It corresponds to the general tendencies of image construction during the fin-de-siecle, and anticipates the approaching expressionistic and avant-garde trends.

The images, which I call the 'prodigal sons' can be found in, at least, three of Strindberg's later works: Black Banners, Alone and The House that Burned. All three episodes involve the returning sons and share the following common themes: fathers' fear to meet their sons in anticipation of seeing something disturbing and horrible, and their strong sense of guilt for their sins and crimes, plus attempts to hide and run away from the scene. In addition, these are the ugly, deformed, and animallike appearance of the sons, and their hatred of the older generation and of those who are better off.

In Black Banners, Zachris' greatest nightmare is to meet his long lost son from his previous marriage. When the son arrives at Christmas Eve and claims his hereditary rights, Zachris recognizes his face, but flees and hides in a closet. In The House that Burned Strindberg explains the nature of the fathers' crimes including the 'liberating' education of their children. The 'prodigal son' - the Stranger - returns when his father is already dead, and he exposes the latter's secrets and sins, as well as the corruptive experiences of his own upbringing, such as reading the memoirs of, apparently, Marquis de Sade [Strindberg, 1973, p. 161].The fact that this whole system embodied in the structure of the house is burned down symbolizes Strindberg's condemnation of it. Finally, in Alone, in the state of extreme anguish, the narrator is waiting for the return of his long lost son. Moreover, a rather suspiciously looking young man indeed arrives at his door, and happens to be just someone looking for money. The description of the son in this episode portrays the outcomes of the fathers' crimes [Strindberg, 1968, p.401-402].

This imagery of the 'prodigal sons' represents the intersection of Strindberg's religious and philosophical perspectives characteristic of 
his world outlook after the Inferno crisis. One theme is his metaphysical hopelessness rooted in the particular version of Christian faith that he converted to later in life. "In Strindberg's case, religious conversion is not an edifying, but on the contrary a morbid and saddening spectacle; it is equal to a declaration of complete spiritual bankruptcy" [Heller, 1918, p. 100]. In the 'prodigal son' imagery an extremely strong sense of the fathers' remorse for sins is conveyed. It is saturated with anxiety, confusion, fear, and guilt, which reflects the turn of the century crisis of the sense of enduring certainty rooted in the Enlightenment rationality, and of faith in a compassionate God the Savior. Strindberg's versions of the story about the Prodigal Son is different from the biblical story of love and faith in redemption and salvation. In 'the return of the son' imagery by Strindberg the critique of the Enlightenment rationalism and its derivative nineteenth-century liberalism raises the problem of child-upbringing from the family level to the generational. Fathers in egotistic pursuit of self-emancipation justified by lofty liberal ideas are succeeded by children, whom this pursuit leads into the realm of the demonic and diabolic. Therefore, the sons are 'ugly', 'disproportioned,' and 'deformed', they hate the generation of their fathers, and come to collect their debt. Feeling of responsibility for nurturing these sons drives fathers away from seeing them. They hide in fear of facing the inevitable truth that it is they, who are responsible for breeding such monsters. Such an interpretation is supported by a number of typological similarities of Black Banners with Dostoyevsky's Devils. The title Black Banners, which is symbol for anarchy, echoes the Devils, which depicts the revolutionaries of $19^{\text {th }}$ century Russia. The Devils is a tale about the evil spirits behind the spread of revolutionary nihilism. Importantly, Dostoyevsky saw the nihilism as genetically linked to the nineteenth-century liberalism (hence, the images of the liberal father Verkhovensky and his nihilist son Peter). The similarities between the two authors are hardly accidental. They both, in spite of the age gap, in a sense represent the same philosophical current in the literature of the $19^{\text {th }}$ century that at a certain stage radically questioned the validity of the Enlightenment rationalism and the nineteenth-century liberalism as its consequence leading to unleashing the demonic forces of nihilism. Similarities in the unflattering or outright terrifying portrayals of long lost sons in Dostoyevsky and Strindberg to some extent can be seen as expressing this shared philosophical stance. 


\section{REFERENCES}

Lisovskaia P. A. Tema semeinykh otnoshenii v tvorchestve Avgusta Strindberga: Pozdnii period. Dis. kand. filol. nauk [The Theme of Family Relations in Strindberg's Later Oeuvre. Thesis of PhD diss.]. St. Petersburg, 2002. 205 p. (In Russian)

Heller O. The Eccentricity of August Strindberg. Prophets of Dissent: Essays on Maeterlinck, Strindberg, Nietzsche and Tolstoy. New York, Knopf, 1918, pp. 71105.

Jung C. G. The Special Phenomenology of the Child Archetype. Psyche and Symbol: A Selection from the Writings of C. G. Jung. Ed. by V. de Laszlo. New York, Garden City, 1958, pp. 132-147.

Lloyd R. The Land of Lost Content: Children and Childhood in Nineteenth-Century French Literature. Oxford, Clarendon, 1992. 271 p.

Olsson U. Levande död: Studier i Strindbergs prosa. Eslöv, B. Östlings bokförlag Symposion, 1996. $512 \mathrm{p}$.

Robinson M. Strindberg and Autobiography: Writing and Reading a Life. Norwich, Norvik P, 1986. 192 p.

Ruff F. Suffering Angels: Images of Children in Nineteenth Century Drama. Diss. City U of New York, 1991. 204 p.

Stounbjerg P. Between realism and modernism. The Cambridge Companion to August Strindberg. Ed. by M. Robinson. New York, Cambridge UP, 2009, pp. 47-57.

Strindberg A. Black Banners: Genre Scenes from the Turn of the Century. Trans. by Donald K. Weaver. New York, Oxford, Peter Lang, 2010. Studies on Themes and Motifs in Literature 101. $201 \mathrm{p}$.

Strindberg A. A Dream Play and Four Chamber Plays. Trans. by W. Johnson. Seattle; London, $\mathrm{U}$ of Washington P, 1973. 278 p.

Strindberg A. En blå bok I [A Blue Book I]. August Strindbergs Samlade Verk 65. Nationalupplaga. 668 p.

Strindberg A. Götiska rummen [The Gothic Rooms]. August Strindbergs Samlade Verk 53. Nationalupplaga. Stockholm, Norstedts, 2001. 480 p.

Strindberg A. Inferno, Alone, and Other Writings. Trans. by D. Coltman and E. Sprinchorn. Ed. by E. Sprinchorn. Garden City, Anchor Books, 1968. 424 p.

Szalczer E. Writing Daughters: August Strindberg's Other Voices. Norwich, Norvik P, 2008. 224 p.

\section{Полина Александровна Лисовская}

кандидат филологических наук,

доцент кафедры скандинавской и нидерландской филологии

филологического факультета СПБГУ.

Санкт-Петербургский государственный университет,

Российская Федерация, 199034, Санкт-Петербург,

Университетская наб., д. 7-9

E-mail:p.lisovskaya@spbu.ru 


\section{Polina Lisovskaya}

$\mathrm{PhD}$ in Philology, Associate Professor,

Department of the Scandinavian and Dutch Philology,

Faculty of Philology, St. Petersburg State University.

7-9, Universitetskaya nab., St. Petersburg 199034, Russia

E-mail:p.lisovskaya@spbu.ru

Статья поступила в редакцию 28.03.16, принята к публикации 30.05.16 